\title{
MALAYSIAN RISK MANAGEMENT COMMITTEES AND FIRMS' FINANCIAL PERFORMANCE
}

\author{
Roslida Ramlee ${ }^{1}$ and Normah Ahmad ${ }^{2}$ \\ ${ }^{1}$ MARA University of Technology, Kota Kinabalu, Sabah, Malaysia \\ E-mail: roslidaramlee7942@gmail.com \\ ${ }^{2}$ MARA University of Technology, Arau, Perlis, Malaysia \\ E-mail: normahahmad@uitm.edu.my
}

\begin{abstract}
The establishment of a risk management committee (RMC) as a board committee is mandatory for finance firms in Malaysia. But for firms in the non-finance sector, the practice is still voluntary. This study examined (1) the roles and responsibilities of RMC on Malaysian non-finance firms and (2) the relationship between RMC and firms' financial performance. The data collected were from the corporate annual reports and for the period 2009 - 2016. Firms' financial performance was measured by return on assets (ROA), return on equity (ROE) and Tobin's Q. The RMC were proxied by five (5) characteristics: its size, its independence, the existence of $\mathrm{CEO} /$ $\mathrm{COO} / \mathrm{CRO} / \mathrm{CFO}$ on $\mathrm{RMC}$, their knowledge and expertise, and frequency of RMC meetings. The data were analyzed using the Panel Data Analysis Stata13. This study found that the responsibilities of RMC vary from simple reviewing and risk categorizing to approving risk strategies, reporting to the board of directors and providing assurance on the risk management process. This study showed that the existence of $\mathrm{CEO} / \mathrm{COO} / \mathrm{CRO} / \mathrm{CFO}$ on $\mathrm{RMC}$ and their knowledge and expertise are associated with firms' financial performance. This study concluded that though RMC in non-finance firms is a voluntary practice, their establishment is one of the important strategies of corporate governance reform.
\end{abstract}

Keywords: RMC, corporate governance, Malaysia

ARTICLE INFO

Article History:

Received: 11 March 2020

Accepted: 2 July 2020

Published: 31 August 2020 


\section{INTRODUCTION}

Under the Agency Theory, differences in risk preferential between shareholders and managers will result in the monitoring needs of the firms' risk activities by the board of directors (Jensen \& Meckling, 1976; Subramaniam, McManus, \& Zhang, 2009). The increase in risk volume and risk complexities faced by a business firm today has broadened the role of an audit committee from the traditional role of ensuring integrity and transparency of financial reporting to include risk management and internal control. The additional workload pressures the audit committee which also has limited resources, skills and time to perform effectively (Subramanian et al., 2009, Bugalla, Kallman, Mandel, \& Narvaez, 2012; $\mathrm{Ng}$, Chong, \& Ismail, 2013). The Corporate Governance Guidelines of the Australian Stock Exchange (ASX, 2010) had suggested the establishment of a risk management committee (RMC) or other specific committees as the appropriate board committee for risk oversight, risk management, and internal control. Thus, many firms have established RMC to lessen the workload of the audit committee.

In Malaysia, the Malaysian Code on Corporate Governance 2012 (MCCG, 2012) states that the Board of a public listed firm should establish an effective risk management and internal control framework. The MCCG (2012) also recommends that the Board should disclose the features of its risk management and internal control framework, and the adequacy and effectiveness of this framework. In order to strengthen the area of risk management and internal control practices in a firm, the Securities Commission has further released a new Malaysian Code on Corporate Governance 2017 (MCCG, 2017) which recommends that board should establish a RMC which comprises a majority of independent directors to oversee the firm's risk management framework and policies and its implementation. Bugalla et al. (2012) suggest that a RMC has the primary duty for risk oversight, risk processes, and practices; and proposed that an audit committee should be independent of a RMC to preserve the integrity and protect against fiduciary misconduct.

The establishment of a RMC is a mandatory requirement for Malaysian public listed firms in finance sectors and its roles and responsibilities are stipulated in the Guideline on Corporate Governance Standards on 
Directorship for Development Financial Institutions issued by the Central Bank of Malaysia (BNM, 2010). Thus, RMC is not new to the finance and insurance industries. Although the practice is voluntary for non-finance firms, Soltanizadeh, Abdul Rasid, Golshan, Quoquab, and Basiruddin (2014) found that the establishment of a RMC in non-finance firms for the year s2009-2012 had increased. However, the roles of a RMC in risk management are relatively unexplored and the literature in that field is limited and scant. Tufano (1996) added that the lack of research on risk management committees is due to the lack of meaningful data on risk management practices. Subramaniam and Carey (2011) reported that the establishment of a formalized system of risk management in an organization is a more recent development. The establishment of a RMC is seen to complement the oversight function of the BOD and able to reduce the tasks of the audit committee. Studies on RMCs have gained popularity as an important oversight committee but the studies focus more on (1) factors influencing the establishment of a RMC (e.g., Kakanda, Salim, \& Chandren, 2018; Ling, Mat Zain, \& Jaffar, 2014); (2) relationship between characteristics of a RMC and firms' risk taking (e.g., Ng et al., 2013; Kallamu, 2015); (3) RMC and firms' disclosure (e.g., Abdullah \& Abdul Shukor, 2017) and (4) relationship between characteristics of a RMC and corporate governance (e.g., Aebi, Sabato, \& Schmid, 2012).

Risk management is a way to manage risks that may affect the achievement of a firm's performance. The Committee of Sponsoring Organizations of the Treadway Commission (COSO) - (COSO, 2004) had issued the Enterprise Risk Management (ERM) an Integrated Framework that describes the essential components, principles, and concepts of risk management for the entire organization regardless of size. Firms that implement ERM can identify the risks contained in the business operations, evaluate how resources can be allocated to improve capital efficiency, prevent duplication of processes, and reduce the cost of risk management (Saeidi, Sofian, \& Rasid, 2014). To be effective, ERM requires adequate oversight, thus leading to the setting up of the RMC by the firm's commissioner. The $\mathrm{RMC}$ is the strength of a firm enabling it to achieve its business objectives and to improve the quality of financial reporting as a safeguard of a firm's reputation, and ultimately improve firm performance. Meanwhile, the COSO (2017) had proposed an ERM framework that integrates ERM with strategy and performance. Since the RMC is responsible for inspecting, 
monitoring, and assessing the principles, policies, strategies, processes, and risk management control, it will generate a better risk management process, so that the risks that the firm faces can be reduced and even prevented and ultimately influence the improvement of firm performance. Linke and Florio (2018) lamented the broad spectrum of ERM implementation components and it will continue to remain difficult in developing valid and reliable measures for the risk management construct.

The roles and responsibilities of a RMC and its effect on firm performance were examined in this study. In particular, the objectives of this study were to examine: (1) the roles and responsibilities of a RMC on Malaysian non-finance firms, and (2) the relationship between a RMC and firms' financial performance.

\section{LITERATURE REVIEW}

\section{Roles of RMC}

The ERM Integrated Framework by Committee of Sponsoring Organization (COSO) (2017) describes the common responsibilities of a RMC to include (1) to determine the firm's risk management strategies; (2) to evaluate firm's risk management operations; (3) to assess firm's financial reporting; and (4) to ensure that a firm complies with the laws and regulations that govern its operations. Subramaniam et al. (2009) stated that the existence of a separate RMC focusing on the risk profile was to increase the quality of internal monitoring and quality of financial reporting concerning risk management. Iyengar, Land, and Zampelli (2010) supported the idea that the board committee was able to influence the quality of financial reporting. The existence of a separate RMC has the job profile on broad areas of risks including internal and external risks. The main function of an RMC in an ERM, according to COSO (2017) and Baxter, Bedard, Hoitash, and Yezegel (2013) is to assist the board of directors in risk oversight.

The establishment of a separate or a stand-alone RMC is seen as being able to implement its oversight function for the risk management profile of the firm. Compared to the other board committees such as the audit committee, it has a lot of duties on internal control and accounting 
transactions. The lack of expertise among the members of the audit committee in the business industry and the investment opportunity makes it difficult to evaluate these types of risks (Zaman, 2001). The establishment of a RMC is recognized as one of the ERM governance structures (Deloitte, 2013). A firm that establishes a RMC demonstrates a greater awareness of the importance of risk management and control (COSO, 2017). The AICPA-CIMA research series by Beasley and Hancock (2010) reported the movement of firms to strengthen enterprise risk oversight through a separate risk committee. A conceptual study by Cernauskas and Tarantino (2009) cited that such a creation would be able to reduce future risk management failures that coincide with the current global financial crisis. Such an establishment should enhance the activities of risk management within a particular organization.

Since the roles of RMC in non-finance firms are not described anywhere in the guidelines and best practices, this study was initiated to identify these roles.

\section{RMC and Firms' Performances}

Prior studies found an association between board committee and firm performance, but the strength of the association depends on many factors including the characteristics of the board committee (Linke \& Florio, 2018). Klein (1998) found a significant association between firm performance and the percentage of inside directors on the board committee. Aldamen, Duncan, Kelly, McNamara, and Nagel (2012) found an association between firm performance and the percentage of external directors on the board committee. Yasser, Entebang, and Mansor (2011) found a special linkage between firm performance and board committee. The frequency of board committee meetings is also related to firm performance ( $\mathrm{Ng}$ et al., 2013). All the previous studies are based on the board committee such as the audit committee, remuneration committee, investment committee, and others. Therefore, the study is motivated to find out if a specific RMC could also be associated with firm performance.

The study hypothesized that five (5) characteristics of a RMC (size of $R M C$, independence of RMC members, knowledge and expertise of RMC members, the existence of $\mathrm{CEO} / \mathrm{COO} / \mathrm{CFO} / \mathrm{CRO}$ on $\mathrm{RMC}$, and frequency of 
$R M C$ meetings) are associated with financial performance of non-financial firms in Malaysia. The effect of RMC on the relationship of ERM and firm performance may be different based on the following characteristics: the size of $R M C$, independence of $R M C$ members, knowledge and expertise of RMC members, the existence of COO/CFO/CRO/CEO on RMC and frequency of RMC meetings

\section{Size of RMC}

Larger firms have larger boards and larger boards can control the management and improve financial and non-financial performance by reducing agency costs (Coles, Daniel, \& Naveen, 2008). A larger board committee has more resources to utilize by reducing agency costs (Pearce \& Zahra, 1992); the knowledge and skills for monitoring risk (Tao \& Hutchinson, 2013) and increase the status and power of the committee (Kalbers \& Fogarty, 1993). However, more members in the committee may increase free riders (Karamanou \& Vafeas, 2005). A larger committee size may also lead to less activity and presence of members who have lost focus (Dalton et al., 1999). Risk committee size is used as a proxy for a company's willingness to invest in board resources to increase the enterprise stature and influence of the committee (Bédard, Chtourou, \& Courteau, 2004). Bédard et al. (2004) stated that a large committee not only provides strength, but the corresponding diversity of opinion within a committee makes it more effective in resolving potential issues

Large size audit committees can protect and control the process of accounting and finance by introducing greater transparency and has a positive impact on the financial performance of a firm (Anderson, Mansi, $\&$ Reeb, 2004). Bouaziz (2012) found that the size of an audit committee in 26 Tunisian firms to have a significant positive association with firm performance. In a study on 175 Malaysian public listed firms as in 2010, Nickmanesh, Zohoori, Musram, and Akbari (2013) found that RMC size has a negative significant impact on firm performance, measured by return on firm's assets and no significant impact on firm performance measured by turnover. Despite mixed results, the alternate hypothesis is that:

H1: There is a significant association between the size of a RMC and firm performance. 


\section{Independence of RMC Members}

The independence of board members is one of the key elements in corporate governance (Abdul Rahman \& Salim, 2010). Independent directors oversee management actions (Fama \& Jensen, 1983) because they do not have personal interests in the firm and make fair judgments without any bias (Beasley, Carcello, Hermanson, \& Lapides, 2000). Prior studies on audit committees have found that independent directors in an audit committee are likely to improve a firm's financial performance (AlMatari, Al-Swidi, \& Fadzil, 2014; Shah, Butt, \& Saeed, 2011) and the quality of information disclosed (Beasley \& Salterio, 2001). Bryan, Liu, and Tiras (2004) evidenced that the independence of the audit committee positively influences the quality of earnings. $\mathrm{Ng}$ et al. (2013) in a study of Malaysian insurance firms for 2003-2011 found that the independence of a $\mathrm{RMC}$ is correlated with risk-taking in the firm. In contrast to Klein (1998), Aldamen et al. (2012) found that firm performance is positively affected by external directors on the committee. The mixed findings result in the alternate hypothesis of this study which is:

$\mathbf{H}_{1}$ 2: There is a significant association between the independence of the members of a RMC and firm performance.

\section{Knowledge and Expertise of the RMC Members}

Directors' occupations and experiences as business executives, lawyers, consultants, and/or school professors (Kesner, 1988) assist managers in making decisions and can affect a firm 's value (Hillman et al., 2000). Directors' educational background supports management in a firm's strategic evaluation (Ruigrok, Peck, Tacheva, Greve, \& Hu, 2006). Minton, Taillard, and Williamson (2010) examined the relationship between firms' risk-taking and firms' value with the financial expertise of the board of the US firms before and during the financial crisis. Their study showed that a board committee with financial expertise is positively associated with more risk-taking before the financial crisis but lowers firm's value during the financial crisis. Aldamen et al. (2012) also found that the board committee's financial expertise is associated with firm's performance. In a study on 690 Malaysian firms in the year ended 2003, Yatim (2010) found that firms with greater board expertise are likely to establish a RMC. Thus, the next alternate hypothesis is: 
$\mathbf{H}_{\mathbf{1}}$ 3: There is a significant association between the knowledge and expertise of a RMC and firm performance.

\section{Existence of COO/CEO/CFO/CRO on RMC}

The Chief Risk Officer (CRO) is the person responsible for developing an integrated approach in a risk management system on a firm and plays an important role in supporting the entire risk management program (Saeidi et al., 2014). CRO usually works together with his/her supporting team, which is the RMC (Lam \& Kawamoto, 1997). However, the existence of a Chief Executive Officer (CEO), Chief Operating Officer (COO) and Chief Financial Officer (CFO) as part of the RMC members may benefit the committee from additional expertise and further enhances the decisions made on a risk management program in a firm (Deloitte, 2012). However, there is a lack of research on the effect of $\mathrm{CRO} / \mathrm{CEO} / \mathrm{COO} / \mathrm{CFO}$ in ERM implementation and firm's performance. This study was conducted to provide empirical evidence of the association. Thus, the alternate hypothesis is that:

$\mathbf{H}_{1}$ 4: There is a significant association between the existence of $\mathrm{COO} / \mathrm{CEO} /$ $\mathrm{CRO} / \mathrm{CFO}$ on a $\mathrm{RMC}$ with the firm performance.

\section{Frequency of RMC Meetings}

A meeting is a good venue for RMC members to communicate openly, discuss and achieve a common goal in risk monitoring and control. The number of meetings is an indication of the level of effort made by the board committees to carry out their tasks (Sori, Ramadili, \& Karbhari, 2009) and enable board committee members to update their knowledge ( $\mathrm{Ng}$ et al., 2013); and also to show the effort of the committees to correct any adverse situations (Abdul Rahman \& Mohamed Ali, 2006). The Bank Negara of Malaysia (BNM) encourages that risk management committees meet once every quarter (BNM, 2010). Thus, the frequency of board meetings is an important board attribute that can affect firm value.

Beasley, Hermanson, Carcello, and Neal (2010) show that firms that commit fraud held fewer audit committee meetings. Bouaziz (2012) found that the frequency of audit committee meetings positively affects the 
financial performance of Tunisian firms. Sharma, Naiker, and Lee (2009) found that misreporting of financial issues is positively related to audit committee meeting frequency. However, Brick and Chidambaran (2010) in a study on firms' data in COMPUSTAT data for the years 1999-2005 found that monitoring activities through audit committee meetings had a negative impact on firm value. Although the results are mixed, the alternate hypothesis is that:

$\mathbf{H}_{1}$ 5: There is a significant association between frequency of RMC meetings and firm performance.

\section{RESEARCH METHODOLOGY}

This study employed a quantitative approach and used corporate annual report content analysis from Bloomberg Database and Bursa Malaysia. The corporate annual reports of non-financial firms from 2009 to 2016 were analyzed resulting in a final sample of 74 firms which is equivalent to 592 firm years. The sample firms in this study were non-financial firms listed on the Main Market of the Malaysian Stock Exchange (Bursa Malaysia). Finance, banking and special purpose acquisition firms (SPAC) were excluded because these firms must comply with other specific regulatory requirements (Haniffa \& Cooke, 2002).

The study defined a RMC as a sub-committee of the board of directors that has its own written constitution and terms of reference (TOR) to assist the board in discharging board duties and responsibilities. The TOR includes the objectives of the committee, its authority, committee meeting affairs, its composition and its roles in ERM. The RMC is considered as a boardlevel RMC if it is clearly stated in the Corporate Information, the Statement of Corporate Governance (SoCG) and the Statement of Internal Control (SoIC); and the members are among the board of directors themselves. The composition of a RMC is either all of them are members of the BOD or a combination of BOD and senior management/head of departments/ internal auditors.

To achieve Objective 1 of the study, detailed information about the roles of RMC was collected through analyzing the information reported 
in the following sections of the corporate annual report: (i) Corporate Information, (ii) Statement of Corporate Governance (SoGC), (iii) Statement of Internal Control (SoIC) or Statement of Risk Management and Internal Control (SoRMIC). The following specific themes, based on the criteria suggested by the Institute of Risk Management (IRM), were used to describe the roles/responsibilities of a RMC in non-finance Malaysian firms: (1) role of a RMC for risk management policies and strategies of the organization; (2) role of a RMC at the strategic and operational level; (3) role of a RMC in risk awareness culture within the organization; (4) role of a RMC in Risk management policies and structures for business units; (5) role of a RMC in the risk management process; (6) role of a RMC in managing risk management issues; (7) role of a RMC in a risk-response process, contingency plan and business continuity programmes and (8) role in reporting risk management affairs.

Table 1 below explains the details of the measurement of the variables used in order to achieve Objective 2 of the study.

Table 1: Measurement of Variables

\begin{tabular}{|c|c|c|}
\hline Variables & Acronym & Measures \\
\hline $\begin{array}{l}\text { Firm performance: } \\
\text { Tobin's Q } \\
\text { Return on Equity } \\
\text { Return on Assets }\end{array}$ & $\begin{array}{l}\text { Tobin's Q } \\
\text { ROE } \\
\text { ROE }\end{array}$ & $\begin{array}{l}\text { Data are taken from the Bloomberg } \\
\text { Database Bursa Malaysia-measured } \\
\text { in percentage }(\%)\end{array}$ \\
\hline Size of RMC & rmcsize & $\begin{array}{l}\text { The number of directors who serve in } \\
\text { the committee }\end{array}$ \\
\hline Independence of directors & Inddir & $\begin{array}{l}\text { No. of independent Non-Executive } \\
\text { Directors who sit on RMC }\end{array}$ \\
\hline $\begin{array}{l}\text { Knowledge and expertise of the } \\
\text { RMC members }\end{array}$ & AcadQ & $\begin{array}{l}\text { No of RMC members with accounting } \\
\text { or finance certificates and background } \\
\text { in } \\
\text { accounting/finance/business }\end{array}$ \\
\hline $\begin{array}{l}\text { Existence of } \\
\text { CEO/COO/CFO/CRO in } \\
\text { the RMC }\end{array}$ & $\operatorname{CCCC}$ & $\begin{array}{l}\text { No. of COO/CEO/CFO/CRO on the } \\
\text { RMC }\end{array}$ \\
\hline $\begin{array}{l}\text { Frequency of RMC } \\
\text { Meetings }\end{array}$ & FreqM & No. of committee meetings per year \\
\hline
\end{tabular}


In order to understand the effect of the characteristics of a $\mathrm{RMC}$ on the financial performance of non-finance Malaysian firms, measured by ROA, ROE and Tobin's Q, the following models were constructed.

\section{Model 1:}

$R O A_{i} \mathrm{t}=\alpha_{\mathrm{i}} \mathrm{t}+\beta 1_{\mathrm{i}} \mathrm{t}$ rmcsize $+\beta 2_{\mathrm{i}} \mathrm{t}$ inddir $+\beta 3_{\mathrm{i}} \mathrm{t}$ acadq $+\beta 4_{\mathrm{i}} \mathrm{t} \operatorname{cccc}+\beta 5_{\mathrm{i}} \mathrm{t}$ freqm + eit

\section{Model 2:}

$\mathrm{ROE}_{\mathrm{i}} \mathrm{t}=\alpha_{\mathrm{i}} \mathrm{t}+\beta 1_{\mathrm{i}} \mathrm{t}$ rmcsize $+\beta 2_{\mathrm{i}} \mathrm{t}$ inddir $+\beta 3_{\mathrm{i}} \mathrm{t}$ acadq $+\beta 4_{\mathrm{i}} \mathrm{t} \operatorname{ccc} c+\beta 5_{\mathrm{i}} \mathrm{t}$ freqm + eit

\section{Model 3:}

Tobins $\mathrm{Q}_{\mathrm{i}} \mathrm{t}=\alpha_{\mathrm{i}} \mathrm{t}+\beta 1_{\mathrm{i}} \mathrm{t}$ rmcsize $+\beta 2_{\mathrm{i}} \mathrm{t}$ inddir $+\beta 3_{\mathrm{i}} \mathrm{t}$ acadq $+\beta 4_{\mathrm{i}} \mathrm{t} \operatorname{cccc}+$ $\beta 5_{\mathrm{i}} \mathrm{t}$ freqm ++ eit

Panel data was used to analyze the data, using the Stata 13 software. Panel data analysis was used because the data was a time series observation across different firms (Baltagi \& Giles, 1998). The analysis was based on Langragian Multiplier (LM) test and poolability test by Breusch and Pagan (1979). The poolability test was used to test the presence of the individual effects of the variables. Diagnostic tests were made to check for multicollinearity, heteroscedasticity and the serial correlation between the data. The final model of the data is the random effect model.

\section{FINDINGS}

The analysis of the information reported in the Corporate Information, SoCG, SoIC or SoRMIC in corporate annual reports found the following roles/responsibilities of a RMC. Not all the RMC in the firms had the same tasks but among others, its roles and specific duties are described in Table 2 below. 
Table 2: Roles of RMC

\begin{tabular}{|c|c|c|}
\hline & Roles of RMC & Specific Duties \\
\hline 1 & $\begin{array}{l}\text { Roles for risk } \\
\text { management policies } \\
\text { and strategies of the } \\
\text { organization }\end{array}$ & $\begin{array}{l}\text { - To set/design/review/revise the plan, policies \& strategies } \\
\text { for risk management } \\
\text { - To communicate the plan, policies \& strategies to } \\
\text { stakeholders, board, employees } \\
\text { - To monitor and refer to the Board any instances involving } \\
\text { material breaches or potential breaches of the Group 's Risk } \\
\text { Management Strategy } \\
\text { - To report to the Board, when necessary, in connection } \\
\text { with the Group's annual reporting responsibilities to Bursa } \\
\text { Malaysia in relation to matters pertaining to the Group's } \\
\text { Risk Management Strategy }\end{array}$ \\
\hline 2 & $\begin{array}{l}\text { Roles at strategic } \\
\text { and operational level }\end{array}$ & $\begin{array}{l}\text { - To oversee \& ensure the quality and integrity of risk } \\
\text { management of the organization } \\
\text { - To consider and make recommendations on behalf of the } \\
\text { Board in connection with compliance by the firm with its risk } \\
\text { management strategy }\end{array}$ \\
\hline 3 & $\begin{array}{l}\text { Roles in risk } \\
\text { awareness } \\
\text { culture within the } \\
\text { organization }\end{array}$ & $\begin{array}{l}\text { - To create a risk awareness culture through education, } \\
\text { training and functional activities } \\
\text { - To ensure that appropriate training in risk awareness \& risk } \\
\text { management is conducted at key levels }\end{array}$ \\
\hline 4 & $\begin{array}{l}\text { Roles Risk } \\
\text { management policies } \\
\text { and structures for } \\
\text { business units (BUs) }\end{array}$ & $\begin{array}{l}\text { - To set/design internal risk plan, policies \& strategies for BUs } \\
\text { - To provide risk management guidance for BUs } \\
\text { - To approve the plan, policies \& strategies of BUs } \\
\text { - To communicate and advice on expected standards in risk } \\
\text { management and decision taken to all BUs }\end{array}$ \\
\hline 5 & $\begin{array}{l}\text { Roles in risk } \\
\text { management } \\
\text { process }\end{array}$ & $\begin{array}{l}\text { - To design/review the risk management process } \\
\text { - To implement internal compliance and control system } \\
\text { procedures to manage risks } \\
\text { - To assess and monitor the effectiveness of control systems } \\
\text { to manage risk } \\
\text { - To ensure that a well-structured \& systematic, process } \\
\text { exists to ensure comprehensive identification, assessment } \\
\text { \& management of risks facing the organization } \\
\text { - To report to the Board on any material changes to the risk } \\
\text { profile of the Group }\end{array}$ \\
\hline 6 & $\begin{array}{l}\text { Roles in risk } \\
\text { management issues }\end{array}$ & $\begin{array}{l}\text { - To coordinate functional activities to advise risk management } \\
\text { issues } \\
\text { - To identify \& allocate resources required for risk management } \\
\text { (budget, human resources, professional advice) } \\
\text { - To ensure adequate resources, expertise and information } \\
\text { to manage available risks }\end{array}$ \\
\hline 7 & $\begin{array}{l}\text { Roles in risk } \\
\text { responses process, } \\
\text { contingency plan and } \\
\text { business continuity } \\
\text { programmes }\end{array}$ & $\begin{array}{l}\text { - To formulate contingency plan \& ad-hoc teams for worst } \\
\text { case scenarios }\end{array}$ \\
\hline
\end{tabular}




\begin{tabular}{lll}
\hline \multicolumn{2}{c}{ Roles of RMC } & \multicolumn{1}{c}{ Specific Duties } \\
\hline $8 \quad \begin{array}{l}\text { Roles in reporting } \\
\text { of risk management } \\
\text { affairs }\end{array}$ & $\begin{array}{l}\text { - } \\
\text { - To prepare risk management reports } \\
\text { being addressed and mitigated } \\
\text { - To communicate risk management reports to the board of } \\
\text { directors \& stakeholders }\end{array}$ \\
\hline
\end{tabular}

The results as shown in Table 3 show the ROA of non-finance Malaysian firms ranges from $-3.62 \%$ to $59.78 \%$ and averages $7.20 \%$. The ROE ranges from $-10.58 \%$ to $124.41 \%$ and averages $1.37 \%$. Tobin's Q is as low as $0.4 \%$ and not exceeding 5.2\% and the average is $1.23 \%$. The firms in the study have a RMC with an average size of 3 directors serving on the committee and the number varies from a minimum of 1 director to a maximum of 6 directors. The average number of independent directors that serve on the committee is 2 , a maximum of 3 and there are firms without independent directors serving on the board. The average number of RMC members with knowledge and expertise in business, accounting, and finance is 2; there are firms whose directors are without a background in business, accounting, and finance and to a maximum of 6 members with the said knowledge. The existence of $\mathrm{CEO} / \mathrm{CFO} / \mathrm{COO} / \mathrm{CRO}$ is not common in the sample firms. Most firms are without CEO / CFO / COO / CRO serving on the committee and a maximum of 2 members with the said management. The average number of times the RMC meets in a year is 3 with a minimum of 1 to a maximum of 7 meetings.

Table 4 presents the independent variables that are associated with the financial performance of the sample firms. There are 4 variables that have a significant association with ROE ( $p$-value $<0.05$ ) namely the size of RMC, independence of directors who serve on the RMC, knowledge, and expertise of the RMC and the $\mathrm{COO} / \mathrm{CEO} / \mathrm{CFO} / \mathrm{CRO}$ serves on the committee. Meanwhile, 3 variables that have a significant association with firm performance measured by ROA, and these are independence of directors who serve on the RMC, knowledge, and expertise of the RMC and the $\mathrm{COO} / \mathrm{CEO} / \mathrm{CFO} / \mathrm{CRO}$ serves on the committee. Finally, only 2 variables can be associated with firm performance measured by Tobin's Q; knowledge and expertise of the $\mathrm{RMC}$ and the $\mathrm{COO} / \mathrm{CEO} / \mathrm{CFO} / \mathrm{CRO}$ serves on the 
committee. The overall findings evidenced that the knowledge and expertise of the $\mathrm{RMC}$ and the $\mathrm{COO} / \mathrm{CEO} / \mathrm{CFO} / \mathrm{CRO}$ serving on the committee can be associated with firm financial performance measured by ROE, ROA and Tobin's $Q$. The expert directors who serve on board committees can credibly transmit information and reduce information asymmetry between insiders and outsiders. The result also supports Deloitte (2013) that the existence of $\mathrm{CEO} / \mathrm{COO} / \mathrm{CFO} / \mathrm{CRO}$ may benefit the $\mathrm{RMC}$ and can assist in making an efficient decision on risk management.

Table 3: Descriptive Statistics

\begin{tabular}{lcccc}
\multicolumn{1}{c}{ Variables } & Mean & Median & Maximum & Minimum \\
\hline ROE & 1.3793 & 8.7781 & 124.4163 & -10.5866 \\
ROA & 7.200 & 4.4765 & 59.7850 & -3.6240 \\
Tobin's Q & 1.2391 & 0.9850 & 5.2411 & 0.4394 \\
rmcsize & 3 & 3 & 6 & 1 \\
inddir & 2 & 1 & 3 & 0 \\
acadq & 2 & 2 & 6 & 0 \\
cccc & 0 & 0 & 2 & 0 \\
freqm & 3 & 3 & 7 & 1 \\
\hline
\end{tabular}

Table 4: Langragian Multipler Test for Random Effects

\begin{tabular}{lccc} 
& ROE & ROA & Tobin's Q \\
p-value $<0.05$ & p-value $<0.05$ & p-value $<0.05$ \\
\hline rmcsize & 0.010 & 0.457 & 0.085 \\
inddir & 0.001 & 0.037 & 0.197 \\
acadq & 0.002 & 0.002 & 0.005 \\
cccc & 0.025 & 0.019 & 0.017 \\
freqm & 0.154 & 0.170 & 0.973 \\
\hline
\end{tabular}

\section{CONCLUSIONS AND RECOMMENDATIONS}

This study examined the roles of RMC in non-finance public listed firms in Malaysia and its effects on the financial performance of the firms. The study was based on a sample of 74 Malaysian non-financial firms. This study found that board-level RMC acts as an agent to the Board of directors, where it ensures all board risk decisions are implemented and monitored 
throughout the organization. Meanwhile, the test results show a significant effect on certain characteristics of the RMC on financial performance measured by ROA, ROE and Tobin's Q. Regarding the characteristics of the RMC on financial performance measured by ROE, the study found that the size of the RMC, independence of directors who serve on the $\mathrm{RMC}$, knowledge, and expertise of the $\mathrm{RMC}$ and the $\mathrm{COO} / \mathrm{CEO} / \mathrm{CFO} /$ $\mathrm{CRO}$ serves on the committee have a significant association with financial performance. On the other hand, the independence of directors serving on the $\mathrm{RMC}$, knowledge, and expertise of the $\mathrm{RMC}$ and the $\mathrm{COO} / \mathrm{CEO} / \mathrm{CFO} /$ CRO serving on the committee have a significant association with ROA. Only the knowledge and expertise of the $\mathrm{RMC}$ and the $\mathrm{COO} / \mathrm{CEO} / \mathrm{CFO} /$ CRO serving on the committee are significantly associated with Tobin's Q. The study has shown that the existence of at least one member of the RMC with knowledge and expertise in accounting, business or finance can influence the financial performance of Malaysian firms in the non-financial sectors. Similarly, the existence of either COO, CEO, CFO or CRO serving on the committee may affect a firm 's financial performance. Despite its voluntary practice, this study suggests the importance of the establishment of a RMC in non-financial firms as a governance mechanism. This study has some limitations as it is limited to information disclosed in the corporate annual reports. Future research could be conducted using a questionnaire or an interview survey.

\section{REFERENCES}

Abdul Rahman, R., \& Salim, M. R. (2010). Corporate Governance in Malaysia: Theory, Law and Context. Rawang, Selangor, Malaysia.

Abdul Rahman, R., \& Mohamed Ali, F. H. (2006). Board, audit committee, culture and earnings management: Malaysian evidence. Managerial Auditing Journal, 21(7), 783-804.

Abdullah, M., \& Abdul Shukor, Z. (2017). The comparative moderating effect of risk management committee and audit committee on the association between voluntary risk management disclosure and firm performance. Jurnal Pengurusan, 51(2017), 159-172. 
Aebi, V., Sabato, G., \& Schmid, M. (2012). Risk management, corporate governance, and bank performance in the financial crisis. Journal of Banking \& Finance, 36(12), 3213-3226.

Aldamen, H., Duncan, K., Kelly, S., McNamara, R., \& Nagel, S. (2012). Audit committee characteristics and firm performance during the global financial crisis. Accounting \& Finance, 52(4), 971-1000.

Al-Matari, E. M., Al-Swidi, A. K., \& Fadzil, F. H. B. (2014). Audit committee characteristics and executive committee characteristics and firm performance in Oman: Empirical study. Asian Social Science, 10(12), 98-113.

Anderson, R. C., Mansi, S. A., \& Reeb, D. M. (2004). Board characteristics, accounting report integrity, and the cost of debt. Journal of accounting and economics, 37(3), 315-342.

ASX, C. G. C. (2010). Corporate governance principles and recommendations with 2010 amendments. Available at: www. asx. com. au/governance/ corporate-governance.htm (accessed on 24 October 2012).

Baltagi, B. H., \& Giles, M. D. (1998). Panel data methods. Statistics Textbooks and Monographs, 155, 291-324.

Baxter, R., Bedard, J. C., Hoitash, R., \& Yezegel, A. (2013). Enterprise risk management program quality: Determinants, value relevance, and the financial crisis. Contemporary Accounting Research, 30(4), 1264-1295.

Beasley, M. S., \& Salterio, S. E. (2001). The relationship between board characteristics and voluntary improvements in audit committee composition and experience. Contemporary Accounting Research, 18(4), 539-570.

Beasley, M. S., Carcello, J. V., Hermanson, D. R., \& Lapides, P. D. (2000). Fraudulent financial reporting: Consideration of industry traits and corporate governance mechanisms. Accounting Horizons, 14(4), 441454. 
Beasley, M. S., Hermanson, D. R., Carcello, J. V., \& Neal, T. L. (2010). Fraudulent financial reporting: 1998-2007: An analysis of US public companies. Committee of Sponsoring Organization of the Treadway Commission.

Bédard, J., Chtourou, S. M., \& Courteau, L. (2004). The effect of audit committee expertise, independence, and activity on aggressive earnings management. Auditing: A Journal of Practice \& Theory, 23(2), 13-35.

BNM. (2010). Guideline on Corporate Governance Standards on Directorship for Development Financial Institutions.

Bouaziz, Z. (2012). The impact of auditor size on financial performance of Tunisian companies. Faculty of Economics and Management. Sfax University, Tunisia.

Branson, B. C., \& Hancock, B. V. (2010). Are you identifying your most significant risks?. Strategic Finance, 92(5), 29-36.

Brick, I. E., \& Chidambaran, N. (2010). Board meetings, committee structure, and firm value. Journal of Corporate Finance, 16(4), 533-553.

Bryan, D., Liu, C., \& Tiras, S. L. (2004). The influence of independent and effective audit committees on earnings quality. Available at SSRN, 488082.

Bugalla, J., Kallman, J., Mandel, C., \& Narvaez, K. (2012). Best practice risk committees. The Corporate Board, 33(194), 6-10.

Cernauskas, D., \& Tarantino, A. (2009). Operational risk management with process control and business process modeling. The Journal of Operational Risk, 4(2), 3-17.

Coles, J. L., Daniel, N. D., \& Naveen, L. (2008). Boards: Does one size fit all? Journal of Financial Economics, 87(2), 329-356.

COSO, T. C. o. S. O. o. t. T. C. (2004). Enterprise Risk Management: Executive Summary Retrieved from New York. www.coso.org. 
COSO, T. C. o. S. O. o. t. T. C. (2017). ERM Integrated Framework.

Dalton, D. R., Daily, C. M., Johnson, J. L., \& Ellstrand, A. E. (1999). Number of directors and financial performance: A meta-analysis. Academy of Management Journal, 42(6), 674-686.

Deloitte. (2012). Deloitte Global Report: Quality \& Risk. Retrieved from https://public.deloitte.com/media/0564/pdfs/DTTL_2012GlobalReport. pdf

Deloitte. (2013). Deloitte Global Impact 2013 Report. Retrieved from https:/www2.deloitte.com/content/dam/Deloitte/global/Documents/ About-Deloitte/gx-gr13-main-report.pdf

Fama, E. F., \& Jensen, M. C. (1983). Separation of ownership and control. The Journal of Law and Economics, 26(2), 301-325.

Haniffa, R. M., \& Cooke, T. E. (2002). Culture, corporate governance and disclosure in Malaysian corporations. Abacus, 38(3), 317-349.

Iyengar, R. J., Land, J., \& Zampelli, E. M. (2010). Does board governance improve the quality of accounting earnings? Accounting Research Journal, 23(1), 49-68.

Jensen, M. C., \& Meckling, W. H. (1976). Theory of the firm: Managerial behavior, agency costs and ownership structure. Journal of Financial Economics, 3(4), 305-360.

Kakanda, M. M, Salim, B., \& Chandren, S. (2018). Risk management committee characteristics and market performance: Empirical evidence from listed financial service firms in Nigeria. International Journal of Management and Applied Science, 4(2), 6-10.

Kalbers, L. P., \& Fogarty, T. J. (1993). Audit committee effectiveness: An empirical investigation of the contribution of power. Auditing, 12(1), 24-49.

Kallamu, B. S. (2015). Risk management committee attributes and firm performance. International Finance and Banking, 2(2), 2374-2089. 
Karamanou, I., \& Vafeas, N. (2005). The association between corporate boards, audit committees, and management earnings forecasts: An empirical analysis. Journal of Accounting Research, 43(3), 453-486.

Kesner, I. F. (1988). Directors' characteristics and committee membership: An investigation of type, occupation, tenure, and gender. Academy of Management Journal, 31(1), 66-84.

Klein, A. (1998). Firm performance and board committee structure. The Journal of Law and Economics, 41(1), 275-304.

Lam, J. C., \& Kawamoto, B. M. (1997). Emergence of the chief risk officer. Risk Management, 44(9), 30-35.

Ling, L. C., Mat Zain, M., \& Jaffar, N. (2014). Determinants of risk management committee formation: An analysis of public-held firms. Academy of Accounting and Financial Studies Journal, 18(1), 37-47.

Linke, A., \& Florio, C. (2019). Enterprise Risk Management Measurement: Insights from an Interdisciplinary Literature Review. In Multiple Perspectives in Risk and Risk Management (pp. 37-54). Cham: Springer.

MCCG. (2012). The Malaysian Code on Corporate Governance. Kuala Lumpur: Securities Commission, Malaysia.

MCCG. (2017). The Malaysian Code on Corporate Governance Kuala Lumpur: Securities Commission Malaysia.

Minton, B. A., Taillard, J., \& Williamson, R. (2010). Do independence and financial expertise of the board matter for risk taking and performance? Charles A. Dice Center Working Paper, 14.

Ng, T. H., Chong, L. L., \& Ismail, H. (2013). Is the risk management committee only a procedural compliance?. The Journal of Risk Finance, 14(1), 71-86.

Nickmanesh, S., Zohoori, M., Musram, A. M., \& Akbari, A. (2013). Enterprise risk management and performance in Malaysia. Interdisciplinary Journal of Contemporary Research in Business, 5(1), 670-707. 
Pearce, J. A., \& Zahra, S. A. (1992). Board composition from a strategic contingency perspective. Journal of Management Studies, 29(4), 411438.

Ruigrok, W., Peck, S., Tacheva, S., Greve, P., \& Hu, Y. (2006). The determinants and effects of board nomination committees. Journal of Management \& Governance, 10(2), 119-148.

Saeidi, P., Sofian, S., \& Rasid, S. Z. B. A. (2014). A proposed model of the relationship between enterprise risk management and firm performance. International Journal of Information Processing and Management, 5(2), 70-80.

Shah, S. Z. A., Butt, S. A., \& Saeed, M. M. (2011). Ownership structure and performance of firms: Empirical evidence from an emerging market. African Journal of Business Management, 5(2), 515-523.

Sharma, V., Naiker, V., \& Lee, B. (2009). Determinants of audit committee meeting frequency: Evidence from a voluntary governance system. Accounting Horizons, 23(3), 245-263.

Soltanizadeh, S., Abdul Rasid, S. Z., Golshan, N., Quoquab, F., \& Basiruddin, R. (2014). Enterprise risk management practices among Malaysian firms. Procedia-Social and Behavioral Sciences, 164, 332337.

Sori, Z. M., Ramadili, S. M., \& Karbhari, Y. (2009). Audit committee and auditor independence: the bankers' perception. International Journal of Economics and Management, 3(2), 317-331.

Subramaniam, N., \& Carey, P. P. (2011). Risk management, governance and assurance. Managerial Auditing Journal, 26(7).

Subramaniam, N., McManus, L., \& Zhang, J. (2009). Corporate governance, firm characteristics and risk management committee formation in Australian companies. Managerial Auditing Journal, 24(4), 316-339.

Tao, N. B., \& Hutchinson, M. (2013). Corporate governance and risk management: The role of risk management and compensation 
committees. Journal of Contemporary Accounting \& Economics, 9(1), 83-99.

Tufano, P. (1996). Who manages risk? An empirical examination of risk management practices in the gold mining industry. The Journal of Finance, 51(4), 1097-1137.

Yasser, Q. R., Entebang, H. A., \& Mansor, S. A. (2011). Corporate governance and firm performance in Pakistan: The case of Karachi Stock Exchange (KSE)-30. Journal of Economics and International Finance, 3(8), 482-491.

Yatim, P. (2010). Board structures and the establishment of a risk management committee by Malaysian listed firms. Journal of Management \& Governance, 14(1), 17-36.

Zaman, M. (2001). Turnbull - Generating undue expectations of the corporate governance role of audit committees. Managerial Auditing Journal, 16(1), 5-9. 